\title{
Certain European Legal Aid Offices
}

$\mathrm{B}$ Отн fundamentally and superficially legal aid is substantially the same in Europe as in the United States. The legal problems are those that arise out of desertion, abandonment of children, cruelty, bastardy, death of a parent, adoption, loss of a job, collection of wages, chattel mortgages, usury, non-payment of rent, collection of bills and other unlike relationships. These legal problems are peculiarly those of persons who cannot afford to pay court costs or counsel fees. Since most cases are disposed of by giving advice or an attempt to effect a conciliation, or im matrimonial cases, a reconciliation, only 5 to 10 per cent of the cases go to litigation. Here the legal aid attorney generally prevails in about 80 per cent of the trials. Thus to hundreds of thousands of people equal justice is made available. In a high proportion of the cases, taken individually, the attorney is only able to lend a sympathetic ear to the tale of the client. For if the basis of the difficulty lies in the meanness of the individual whose presence is needed for the support or care of the children, or if the family is too large for the incoine that can be made available, or the ill health or mental disease of one of the parties, or overcrowding of two or more families in the quarters of one, then it often happens that the remedy required is not legal but economic or psychotherapeutic, or even religious. The attorney might recognize the difficulty, but not be qualified to cure it. Or if qualified, the needed hours of time prolonged over months would make it impossible for him to attempt the task. Again, lack of funds for investigation or treatment may be a complete barrier against progress. In every clinic the staff and cooperating attorneys frequently become disheartened over the number of people whose disappointments and injustices they are unable to redress. However, the mere act of listening on the part of a sympathetic person often does the client more good actually than anything else that could be done.

Although the above indicates that the course of legal aid is in general quite uniform, nevertheless it varies in important aspects in different places. For instance, one who is familiar with the statistical report of the Boston Society would be surprised to find that we in California have almost no workmen's compensation cases. But if he looks at the statutes of the two states, he will find that under Massachusetts law there is no state administrative commission to which the laborer can go for necessary assistance as he can in California. Abroad we find a parallel situation. English societies, for instance, devote much time to this class of relief, whereas the German states give almost no attention to it, the reason being that the German system has commis- 
sion administration while the English system, like that of Massachusetts, does not. Again, the English societies are very busy with cases under their rent and mortgage moratoria acts, whereas the same is not so true in some other countries.

In certain communities the work would fail but for the presence of one or more enthusiasts who manage to obtain funds year after year and induce lawyers to give of their time for its support. In every locality the staffs are so sinall in relation to the tasks to be done that rules have had to be adopted liniting the number of those to be served. This financial stringency may be due to the fact that the community in general is unaware of what the legal aid society does.

In a few places only is the society supported in part from legal fees which it is entitled to collect from the other side.

Certain definite general conclusions, gained from examination of legal aid work in the American cities of New York, Chicago, Boston, Philadelphia, Washington, Los Angeles, San Francisco and Oakland, found confirmation in European experiences. They can be summarized as follows:

1. The need for legal aid is far greater than most people realize.

2. The nembers of the bar have been so isolated by their practice and social contacts from the great bulk of our city populations that it can truthfully be said that most lawyers are not even conscious of the fact that to most of our American citizens denial of justice in their personal affairs is normal.

3. That to enable justice and our court system to become available to citizens in larger cities, it is necessary to have permanent offices, located in the communities where these people live.

4. These offices must be staffed with a specially trained personnel, who must be paid a salary so that they can give their full time to this type of work. Some remarks of Mr. Maguire are here pertinent:

". . . The volunteer or unpaid assignment plan is a failure. Adverse critics of the legal profession point to the great charitable service given by medical men and condemn the lawyers as mercenary. But the comparison is unfair. Diseases are common in type, if not in distribution, to all financial strata of mankind. A physician, whether general practitioner or specialist, is as capable of treating the poor as the rich. The rich man's litigation, on the contrary, is entirely different from that of the poor. A counselor well qualified to conduct a great will contest or to advise a powerful corporation might botch a workman's compensation case or a sunall wage collection. He has in a sense lost the common touch. So any scheme based upon casual gratuitous legal assistance to the poor meets the horns of a dilemma. Either unqualified lawyers will be pressed into service or the whole weight of this charity will be cast on the shoulders of practitioners whose low earning power least enables them to bear it. It is true that in small communities, where all lawyers have miscellaneous practices, fairly effective charitable rotation may be worked out. Legal 
aid, however, is a mass metropolitan task and must succeed in great centers of population. The same consideration serves to answer the suggestion that kindly individual lawyers in large cities couple competency with willingness to work for the poor. Individual effort cannot promise continuity, scope or thoroughness to meet the serious and growing need." 1

A consideration of some of the achievements in various countries follows:

VIENNA

Vienna is today famous for the intelligent reforms carried out by the Social Democrats durmg their term of office. The unique position occupied by the Legal Aid Society figured significantly in these reforms. In the city of Vienna, matters coming before the town council which affect the masses are, prior to enactment, referred to the legal aid staff. The staff consists in part of thirty lawyers, each of whom gives one afternoon per week to interviewing clients and handling their cases. This time is given without compensation; quarters and a secretarial staff are provided by the town council. Thus these attorneys are in intimate contact with the poorer people; they know from what they suffer; they are in a position to forecast how legislation will affect them. We know that in America our business firms frequently submit proposed legislation to legal counsel for advice as to how it will affect their businesses. In Vienna it is the poor who have pending legislation submitted to counsel for advice as to how it will affect their lives and livelihood.

On the first Tuesday night of each month, the entire staff meets for the purpose of considering such pending legislation as has been referred to it. Also in attendance are the President of the town council, jurists from the higher courts, and professors from the law faculty of the University of Vienna. Each piece of legislation is first subject to general discussion. Then the chairman appomts a special committee, generally consisting of two, which is to examine the records of the society, consult with others on the needs and effects of such legislation, study the effects of similar legislation elsewhere, make recommendations, and, if necessary, draft amendments thereto. Their report is considered at the next monthly meeting. After discussion and possible revision or amendment, the staff makes a recommendation to the town council.

In a different field the Vienna organization has achieved success. Every social agency must necessarily take steps to see that it is not imposed upon by those able to pay for the services rendered. This is a duty to the donors of the funds. Furthernore as there are never sufficient funds to assist all who are in need, there is a duty to the more needy

1 Maguire, Legal Aid, 9 Encyclopedia of the Sociax ScIEnces (1933) 322. 
to see that they are not denied services by reason of the fact that the charity's resources have been spent on those less needy. The legal aid society must undertake this always difficult duty, complicated further by the obligation of not taking from lawyers any chents who can afford to pay fees.

In Vienna this burden is carried by the Municipal Social Work orgamization. Parties applying for legal aid must present a card from their district warden. If the client is unable to defray his costs, the district warden will go to court and so testify. This testimony is generally sufficient to lead a judge to permit the client to sue in forma pauperis.

A word about this Municipal Social Work organization is in point. The entire city is districted, and the district worker represents every type and form of social agency but one. Thereby visits by a whole host of agency workers to one family are obviated, saving expense to the charities and lessening embarrassment to the indigent. Furthermore it makes for greater efficiency, for it means that a worker in getting acquainted with a family and its needs and position when handling one of its social problems obtams a background of information about the members of the family and their history, capacities and weaknesses, which facilitates his handling of successive problems. In fact, under the district system, the social worker comes pretty close to knowing a good deal about every person and family in his district. The one service not included within the scope of the social worker's activity is medical care and nursing. This, however, parallels that of the social worker.

The Vienna legal aid clinic was set up during the time of the World War to help wives collect alimony and support from their soldier husbands. Once started, it continued to grow, especially during the Socialist regiune following the war, until now it handles approximately 15,000 cases per year.

\section{ENGLAND}

The legal aid system of England is without plan; it just grew. To begin with, there is no general name in counmon use to designate this type of work. "Poor man's lawyer" is the one most frequently used, although other phrases are used, such as "poor persons," etc. The term legal aid is in bad repute, being employed only by "touts" who more or less correspond to our "aunbulance chasers."

The institution known as "poor man's lawyer" counprises generally an office room in a charity institution where on one or two nights a week a lawyer will be present whom poor people may interview concerning their legal perplexities. About seventy different settlenents in London list this as among their activities, and give the schedule of 
hours. The 1935 annual report of Toynbee Hall speaks as follows concerning their work:

"In March, 1891, the first experiment was conducted at Mansfield House Settlement, Canning Town, in a movement which has since spread to all the civilized countries in the world where it has continued to be closely associated with Settlements. The experiment consisted in giving free legal advice to an ignorant and virtually defenseless population who were easy victims of unscrupulous landlords and tradesmen. The exainple of Mansfield House was followed by Toynbee Hall. Since 1898, the 'East London Tenants' Protection Committee' as the group of lawyers who undertook to render free legal advice at Toynbee Hall was called, has continued to render valuable services to the local population, the need for which, strangely enough, appears rather to have mcreased than diminished.

"The Toynbee system is distinctive in that in appropriate cases financial assistance is given in the courts. Free legal advice is popular. Though several lawyers attend every Wednesday evening, it is often impossible for them to deal with all the would-be clients. These clients are dealt with according to certain well-defined rules. Persons with over $£ 4$ a week or \pm 50 savings are not in the ordinaty way advised, and those with between $£ 3$ and $£ 4$ a week are required to show that they are 'poor persons.' A large proportion of the cases are disputes between landlords and tenants, employers and workpeople, or husbands and wives. All who are interviewed are advised. In special cases the Committee's solicitor is instructed to take proceedings, and the reports show that the Committee is able to recover substantial sums of money for its poor clients. In the past year, for example, over two thousand applicants were advised. In fifty-nine cases in which proceedings were taken by the Committee's solicitor, $£ 1,500$ was recovered.

"Until his death the President of the Committee was the Rt. Hon. Lord Justice Scrutton. Mr. G. D. Heath is its honorary solicitor. The Warden and Sub-Warden are members of the Committee of which Mr. Patrick Browne is honorary secretary." 2

In addition to the many settlements in London, innumerable churches and missions do the same work, for the maintenance of a "poor man's lawyer" is looked upon as a proper parish benevolent activity. One may notice it among the exercises of the week that are posted on the doors and gates of the various missions and churches as one goes about London.

At most of the "poor man's lawyer" offices in London, the lawyers generally limit their services to the giving of practical and useful advice which is the most needed. When legal advice is helpful, it is of course given. ${ }^{3}$ When the "poor man's lawyer" finds that litigation is necessary, he advises the client how to proceed, or assistance is received from the Bentham Committee, at No. 1, Lincoln's Inn-fields, London, W. C. 2.

This committee has affiliated with it some forty-six "poor man's

2 Toynbee Hart JubIIEe Report 1884-5-1934-5, p. 20.

3 One who wishes an intimate, well written, serious yet humorous account of how such an institution operates, will find it in (1932) 76 Sor. J. 176. A criticism of the imadequacy of the work is found in GURNEY-CHAMPION, JUSTICE AND THE POOR IN ENGLAND (1926). 
lawyer" centers which are mostly housed in churches and settlements. About 20,000 persons are advised in these centers each year; the committee handles the active legal work. It has a list of solicitors and counsel who volunteer their time, serving in rotation. Since the Law Society's Poor Persons Counmittee handles only high court cases, the latter also refers to the Bentham Committee all cases that must go to the London County Court, Police Courts and adjacent Petty Sessional Courts. Since the people who apply are poor, it is found that the majority of their cases are in these inferior courts. In addition to this, many other charitable organizations in London refer cases to it directly. An additional activity is the gathering of evidence on social-legal questions for presentation to the proper law and rule-making bodies. Last year it reported to the Departmental Committee of the Home Office on the Social Services of the Courts of Summary Jurisdiction. It reports its work for the last three years as follows:

\begin{tabular}{|c|c|c|}
\hline $1935-36$ & $1934-35$ & $1933-34$ \\
\hline $\begin{array}{l}\text { Cases in hand at April 1st.... } \\
\text { Applications during the year }\end{array}$ & $\begin{array}{r}63 \\
703\end{array}$ & $\begin{array}{r}63 \\
636\end{array}$ \\
\hline Total number of cases dealt with during year & $\begin{array}{c}766 \\
1934-35\end{array}$ & $1933-$ \\
\hline
\end{tabular}

The cases were disposed of as follows:

(1) Cases accepted and sent for conduct to solicitors 184 of which

\begin{tabular}{rrr}
159 & 166 \\
111 & 120 \\
43 & 36 \\
5 & 10 \\
\hline 159 & & 166 \\
513 & 470 \\
77 & 51 \\
17 & & 12 \\
\hline 94 & $\frac{63}{766}$ & $\frac{699}{2}$
\end{tabular}

(2) Applicants interviewed and advised.

(a) were settled out of court 150

(b) were the subject of successful prosecution in Court. 30 were unsuccessful 30

(3) Cases carried forward

(a) Being conducted by solicitors

(b) Awaiting further particulars

\begin{tabular}{rrr}
53 & 77 & 51 \\
$\frac{17}{70}$ & $\frac{17}{94}$ & $\frac{12}{63}$ \\
\hline 647 & $\frac{94}{766}$ & $\frac{6}{699}$
\end{tabular}

In Liverpool the practice is much the same except that when litigation is necessary, parties are generally advised to sue in forma pauperis. They then conduct their cases in pro per and if more aid is needed, it is furnished by the magistrate.

The next great group of advisors are the attorneys for the labor unions. One of the means used by labor unions to attract members is to advertise that they give legal aid to their inembers. The unions are especially active in prosecuting employers for violations of laws and 
regulations which have been established for the protection of workers. In general, labor unions gather evidence of occupational diseases and other hazards or conditions which show the need of larger wages or other compensations, different hours of labor or a change in working conditions. At the same time they gather data showing need of reform, furnish to labor leaders in positions of authority the material to use in promoting reform legislation, and then are on the job to see that employers live up to the law. Having large numbers of members, they can afford to retain competent counsel. Whenever a test case is needed to establish the rights of a worker, they are able to take it to the House of Lords if necessary. It might be said that the legal services of the labor unions consist of: (a) pioneering and promotion of health and industrial legislation; (b) advising individuals; and (c) running in labor journals a column or page of "Queries and Replies" on legal questions quite similar to that conducted by Paton for many years in the Banking Lawe Journal.

Many other groups, comprising, for example, wholesalers, retailers, manufacturers, imsurance companies, banks, etc., have counsel who are employed to advise their members individually and further their collective interests. Many of these associations make it a policy to care for the legal problems, not only of the employers who are members of the association, but also of the employees of association members.

In addition to the foregoing, lodges, political parties, clubs and organizations in general who wish to enlarge their membership offer to furnish legal aid to their members.

The most impressive of all is the Poor Persons Committee of the Law Society. It was started in 1914 as a government department and still is financed by the government at an annual cost of $\$ 30,000$ per year, but today the control is in the Law Society. It maintains a head office in Room 785, Royal Courts of Justice, London, W. C. 2, under the able direction of Mr. A. Hassard-Short. Cooperating with the London Committee are 91 committees in the provinces. Since most cases in England must be tried in London, that office handles in court about 3000 cases per year. Curiously enough, about 60 per cent of its work is in divorce matters. In this field it represents husband or wife, or where the circumstances warrant, the co-respondent, for in England all these matters are tried in one suit and the co-respondent is liable for costs and damages. In spite of the apparently great number of matrimonial cases handled, these represent but one-third of the total number of applicants in that field.

The remaming 40 per cent of the cases are so varied that there must be extra and expert assistance; in obtaining this, Mr. Hassard-Short has 
been very successful. He has obtained, upon occasion, free of charge, the cooperation of detective agencies, automobile associations, chartered surveyors, engineers, accountants, medical men, solicitors and barristers. However, he has found the same unwillingness of the medical profession to testify against a fellow practitioner guilty of malpractice as has been encountered in California. Nevertheless the Poor Persons Committee undertakes the prosecution of such cases as well as those against solicitors who have been negligent.

The Society prints imformation for applicants, and provides forms for the applicant to sign, which forms require him to disclose both the financial inability to retain counsel as well as the facts of the case which constitute his ground for complaint.

One of the Society's most useful activities, growing in part out of this work, has been its recommendations in the field of legislation. This has also resulted in altering some of the rules of court. ${ }^{4}$

Due to various causes, legal aid in England is different from that in America. Cases under rent and other moratoria legislation have been referred to in the introduction. Again, one is told that they have no problem of wage assignments. The reason assigned was the efficacy of the Trust Act. It compels an employer to pay the wages of his workmen in coin of the realm (or bank checks, etc.). If the employer pays the employee in goods, or diverts the money to other purposes, the employee may sue and recover all that was due notwithstanding said payment, and the employer is subject to additional penalties as well as criminal prosecution. ${ }^{5}$ However, from a reading of the Act and of the cases interpreting it, I was unable to see just how it prevented wage assignments. Furthermore, legal aid does not represent poor persons in criminal matters; im such cases the magistrates assign counsel for the defense, who are paid a small fee by the government. ${ }^{b}$ Nevertheless some of the railroad unions furnish the aid of counsel to their members even in criminal matters.

In the foregoing discussion mention has not been made of a fact which should always be borne in mind, that much free work is constantly done by solicitors and barristers without reporting it.

If one were to criticize the administration of justice in England, he would say that legal aid was given to the poor as a matter of charity

4 See Statutory Rules and Orders (Sept. 10, 1925) no. 908/L.21, Supreme Court (Poor Persons); amendments (July 20, 1928) no. 566/L. 19; (July 20, 1928) no. 567/L. 20; (Dec. 6, 1929) no. 1116/L. 21; (July 11, 1932) no. 524/L. 16.

G \& 2 WIIL. IV (1831) c. $37 ; 50 \& 51$ VICT. (1887) c. $46 ; 59 \& 60$ VICT. (1896) c. 44; see 14 Hatsbury's Laws of Eingland (2d ed. 1934) 648-659.

6 See Poor Prisoners' Defence Act, L. 930 (20 \& 21 GEo. V (1930) c. 32) and the Statutory Rules and Orders (Dec. 18, 1930) no. 1065 L. 25; (July 3, 1931) no. 532 L. 15 ; (Oct. 6, 1932) no. 823 L. 26. 
rather than enjoyed by them as a matter of right. And, as is so likely to happen in charity, no matter how many organizations contribute funds and assistance, there are usually found great blocks of the population who are overlooked.

\section{GENEVA}

It was in this center of international currents, where the ideas of the world are constantly bombarding all visitors, that there developed in the minds of two persons, each unknown to the other, certain suggestions of great interest.

One, Counselor for the League of Nations, observed that many lawyers have friends and relatives who bring thein problems, sometimes of considerable importance, but which they would not take to a lawyer if a fee were involved. The natural inference followed that there must be other people not in contact with lawyers whose problems were going unsolved. This led him to the conclusion that there must be in existence a rather extensive field of legal activity where the services of a lawyer would prove useful, but which was of no advantage to the lawyer, because of the reluctance of people to incur the expense. Why wouldn't it be possible for such people to take out insurance for legal services? This would be within their means. It would enable them to have the advantage of a lawyer's services when needed, and on a basis which they could pay. The field of accident and health insurance, one of equally great individual unpredictability, affords a precedent. So why not legal insurance? People im moderate circumstances are in need of advice and are not getting it. They are unable to pay the price as single individuals; and they do not want charity. Then why not let such self-supporting people combine to buy their legal advice by group action such as is the case in the payment of insurance premiums. Of course, to prevent abuse, rigid control by the state, moderate dues and classification of types of aid rendered, and supervision by the universities and bar associations would be required.

The other person, a member of the staff of the International Labor Office, had noted how in England, the individual laborer cannot afford to litigate his own cases; but that by joining a union, and paying a most moderate fee, he thereby had the advantage of most capable counsel. He cited the case of a certain laborer in Australia who had a meritorious case, yet to have his right established nust take it to the Privy Council in England for decision. Obviously people of small means cannot afford to pay for such an expensive brand of justice, unless they are able to combine to share the expense. From this he reasoned that great legal assistance could be supplied the middle class by some form of cooperative action. This would be to the advantage of the bar, whose business 
would be increased, the individual, who would receive legal services for which he could pay, and to the social organism as a whole, which always benefits when justice is within reach of the average citizen. This person suggested a very large organization in order to have the strength and the funds to fight, if necessary, to establish principles and leading cases of benefit to its membership as a whole, in addition to the giving of the day to day run of legal advice to individuals.

As a model, he suggested the great trade unions of England, which, in addition to carrying on a campaign of education against the "touts" (ambulance chasers), give to members ordinary relief in obtaining compensation awards, collect for them unemployment insurance, defend them in almost all matters, maintain their rights as passengers against carriers, bring on their behalf criminal actions against employers where the latter are deserving of such, and in extraordinary matters, go often much farther, even to representation in divorce actions.?

At Geneva there is also a very active legal aid society, considering that the population of the city is small-only 142,812 in 1930 . It is operated by the Social Office of the National Protestant Church at Geneva, and in 1934, served 4515 applicants, recovered fr. 56,327.07 $(\$ 19,714.47$ at the then rate of exchange) for its clients, and operated on a budget of fr. 11,300 ( $\$ 3955)$ for the year. The employee in charge is a layman, but he has the support of many volunteer lawyers upon whom he can call for legal aid. Other workers are the girl volunteer students from local social service schools. The law faculty of the University always cooperates when called upon. Its reports were the most complete of any society of its kind, and its written appeal for funds so interesting that one wishes he could produce it here complete in text and typography. The types of service rendered in the 4515 cases handled are tabulated statistically as follows:

$27 \%$ family matters: marriage, husband and wife difficulties, relief, succession and estates.

$19 \%$ financial matters: proceedings on behalf of debtors, recoveries for creditors.

$12 \%$ landlord and tenant.

11\% minors and incompetents: protection of infants, guardianship, trusteeship.

$8 \%$ labor, unemployment, and help for apprentices.

$7 \%$ civil rights: citizenship, naturalization, remstatement.

$6 \%$ insurance, civil responsibility, accidents.

$5 \%$ assistance in civil and criminal judicial proceedings.

7 The above ideas developed out of conversations with Dr. Max Habicht, Counselor on Swiss Law for the League of Nations, and Mr. Sydney Parlett of the International Labor Office. So far as they know, they have never been tried out in practice, and they only advanced them as tentative suggestions of a means of relief where rehef is greatly needed, to be developed by tliose who might be in a position to make something of the suggestions. 
$4 \%$ tax matters.

$1 \%$ miscellaneous.

2437 letters written.

2429 interviews and contacts with administrative officers, judges, court assistants, eic.

2314 letters received.

\section{GERMANY}

It is a little difficult to obtain definite and complete data on legal aid in Germany. Prior to the entrance of the Nazi regime, the development of legal aid had perhaps gone farther in Germany than elsewhere. For instance, a poor person was entitled to submit a statement of his complaint to the court, and, if the court found merit in the claim and possibility of success in the event it was brought to trial, the complainant was permitted to sue in forma pauperis and the court appointed a lawyer to represent him. Lawyers were assigned to such cases in alphabetical order, and when assigned, were compelled to take the cases. For this they received a small fee fron the state. Although statistics are not available, the writer was informed that something like 40 per cent of all the cases commenced in Gerinan courts were suits in forma pauperis. Thus the grant to sue in forma pauperis was not only an exemption from court fees as it is im California, but went further and relieved the party from the obligation to pay the bailiff's cliarges and lawyer's fees. The above was termed "Armenrecht," and was a matter of right of all citizens.

In addition to the above governmental legal aid, for it was in fact a most effective form of legal aid, there existed a wide variety of other offices of a nature similar to those now existing in other countries. Thus there were the Farmers' and Landowners' Leagne, for questions concerning landownership and agriculture; the different unions of landlords and tenants for assisting their members on questions concerning leases and mortgages; the league of sinall garden owners and small settlers in Germany for assisting their members on questions concerning their special interests; the League of Retailers in groceries, dainties and foodstuffs for assisting their members on questions concerning their special branch of trade and especially on tax questions. The above named organizations continue to function today. Then in addition there were a lost of organizations of a charitable or philanthropic type, supported largely by churches, missions, settlements, etc.

Formerly there were some organizations, since disbanded, such as the Workers' Unions, of which five were very great and powerful and which had their own officers to advise workers in their labor disputes, master and servant cases, etc., the importance of which were greater, since in the German law, labor cases could not be handled in the lower 
courts by lawyers, by virtue of the provisions in the Code of Procedure for Labor Courts. The new Nazi organization, the Deutsche Arbeitsfront has been created to carry on their work.

But the legal aid that is administered today is a party matter. Due to the peculiar relation the party bears to the government, it is very difficult to define the legal nature of the services rendered the citizens.

In the National Socialist State, the theory is that legal aid and advice is not a matter of public charity. Every German citizen in reduced circumstances can claim as of right thorough and reliable legal aid and advice. The legal aid is not limited to mere oral information; it includes the drawing up of documents of all kinds, assistance in carrying on law suits in court and before other competent bodies, and where matters require knowledge of a special field, they are referred to lawyers who are fit and trained.

The party maintams in the country 1300 legal aid and advice offices; in fact, wherever courts are held, there must be such an office. Generally, it is in the town hall or city hall, and the hours when attorneys will be on hand are posted in conspicuous places so that the poor will know when to attend. These 1300 offices are grouped into 32 districts, and over all is the headquarters office in Munich. Every lawyer in the land (excepting Jews) must take his turn serving with the others in rotation. This is a professional duty of honor for all German lawyers. If one should seek to be excused, or send a substitute or plead that he is too busy, he will be told that in comparison with the ultimate sacrifice made by millions of his countrymen not so long ago, it is but a small thing to give a few days a year to see that his fellow Germans get justice. In other words, the term "serving one's country" has been broadened into meaning "helping one's fellow citizens." If a lawyer does not take his turn when it comes, he is disbarred. The writer was told that none had refused to take his turn.

The lawyer on duty makes a detailed report of each interview and this is turned over to the district supervisor, who checks to see if the client has been properly advised. The supervisor is in charge of referring cases to specialists, and also follows up cases to see that they are promptly and competently disposed of. The district supervisor as well as the lawyers on duty serve without pay. About 10,000 cases per year pass through the Munich office, and the district supervisor, Dr. Karl Thielo, who gives almost half his time to this job, was enthusiastic over his work, and tireless in his endeavors to see that his poor clients received good treatment.

The statistics show that the Nazi party handles about 200,000 applicants per year. The type of people who apply for relief, and the 
methods of disposition are much the same as in other places, except that Jews are not taken care of and may not apply. On the other hand, party members receive advice regardless of their ability to hire a private attorney.

The specific relief differs somewhat from that which would be given in this country due to differences in the German law. For instance, as about 60 per cent of the landlord's rent is taken by the municipality as a tax, the municipality may remit the tax in cases where the tenant is unable to pay so that the amount of the rent may be decreased pro tanto. Also, an additional allowance can be made to the tenant for the balance of the rent. Of course, if time shows no possibility of the tenant's improving his position, then the landlord can have him removed, the tenant having four to six weeks' time to adjust his affairs to the change. Again, in all larger cities there are municipal pawnshops. The remaining private ones are regulated by state law, are under strict supervision, and if one charges usurious interest the place is closed by the authorities. Consequently, there are few usury cases that come to the attention of the legal aid. Chattel mortgagors have some protection against deficiency judgments. The law is that the loan and the value of the furniture must be approximately the same at the time of the loan, otherwise the contract is immoral; in particular, forfeiture clauses are not tolerated.

In the case of real mortgages there are further differences. No land of a farmer may be put on forced sale without the consent of a special court for rural property; a consent that is very rarely given. Similarly there is protection against forced sales of city property and property used for commercial purposes. Of course, it must appear that the debtor is not at fault and that the levy will not work undue harm upon other creditors.

"Das Honorar darf nicht vom Ausgang des rozesses abhangig gemacht werden" is a maxim of German Jurisprudence, the meaning of which is that a lawyer's honor will not permit the fee to depend on the result of the trial. Hence no contingency fees. The effect is to throw upon the legal aid the duty of prosecuting personal injury actions, which can be done in forma pauperis. In fact, this constituted one of the greatest differences in importance between German and American legal aid, for due to the fact that lawyers could not take a case on a contingent basis, a poor person would have been without any legal relief unless the state granted the armenrecht (in forma pauperis) in order to pursue personal injury actions.

Finally, the Academy of German Law, where meet jurists and outstanding leaders in industry and commerce, constantly studies the sta- 
tistics of economic life and of the workings of the courts, so as to determine the effect of the different laws and drafts new legislation where it appears advisable. The legal aid data is a part of these statistics, and it is the special duty of the German Labor Front to see that the interests of the working population are cared for in any legislation that may be enacted.

As a matter of historical accuracy, the social justice program of the German government dates back to pre-war times. Most of the legal aid work they now claim to be doing had been performed long and ably by the Social Democrats and others so that it was a commonplace matter. The most noticeable innovations of the Nazi regime have been: (a) the exclusion of the Jews; (b) the thoroughgoing organization of the work; (c) Inaking lawyers serve without pay; (d) self advertisement. In view of the abolition of certain organizations which formerly did much of this work, one cannot say whether or not the present regine does more than was done nnder the Social Democrats. But regardless of those facts, the impression given is that the $\mathrm{Nazi}$ party has brought legal advice, attorneys' services, and assistance, even to the prosecution of cases, right to the very door of the people. The belief of the people in what the party was doing brought it great popularity in the early days of its growth. For after all, the sense of justice is deep-rooted in all people, so that any party or organization which not only pronnises to make justice available to all, but appears to carry out its promises is bonnd to receive recognition; and this the Nazis did by compelling every lawyer who was a member of the party to give regular hours to serving clients free of charge in the office of his local legal aid clinic.

Robert E. Stone.

UNIVERStTy of CALIFORNIA, Berkeley, Califorita. 